\title{
INTEGRASI BATAS SUCI TERHADAP TIPOLOGI RUANG BANGUNAN MASJID MODERN DI MAKASSAR
}

\author{
Marwati $^{1 *}$ Sutriani ${ }^{2}$ \\ 1,2Teknik Arsitektur, UIN Alauddin Makassar \\ e-mail: ${ }^{* 1}$ marwati.adalle@uin-alauddin.ac.id, ${ }^{2}$ sutrianishafa@gmail.com
}

\begin{abstract}
Abstrak_Tipologi ruang masjid secara umum terdiri dari area bersih/ suci dan area kotor . Fungsi batas suci pada bangunan masjid merupakan area penghubung antara tempat wudhu dan ruang sholat. Sifat ruang batas suci adalah area bersih. Penelitian ini akan mengetahui tipologi ruang dan menganalisis hubungan batas suci pada tata ruang masjid modern di Makassar. Integrasi pada tata ruang masjid modern dilihat dari indikator tata ruang, letak, bentuk dan sirkulasi pada ruang batas suci. Metode survey, wawancara, dan pengamatan area batas suci pada empat masjid modern yaitu Masjid Raya, Masjid Al-Markas, Masjid Amirul Mukminin dan Masjid H.M. Asyik. Data dianalisis secara deskriptif kualitatif dengan penyajian skema gambar dan tabulasi kemudian dilanjutkan dengan metode reduksi. Hasil penelitian diperoleh pertama, tipologi ruang bangunan masjid modern di Makasar terdiri dari area bersih/suci (ruang sholat dan ruang wudhu), area transisi (ruang batas suci, ruang serambi, dan ruang kantor pengelola) dan area kotor (toilet, ruang penitipan alas kaki, dan dapur). Terdapat perubahan fungsi ruang batas suci sebagai penghubung antara ruang wudhu ke ruang sholat menjadi penghubung antara ruang wudhu/toilet (area bersih/suci dan kotor) ke serambi/ruang sholat (area transisi bersih). Kedua, batas suci ditinjau dari aspek letak, bentuk, sirkulasi, aktivitas pengguna berdampak terhadap tata ruang bangunan masjid. Aspek yang paling berkaitan terhadap batas suci adalah letak dan sistem sirkulasi pengguna pada tata ruang masjid. Konsep desain letak batas suci pada tata ruang bangunan masjid harus menjaga fungsi batas suci sebagai zona clean.
\end{abstract}

Kata kunci: Batas Suci; Tata Ruang Masjid; Masjid Modern.

\begin{abstract}
Typology of mosque space in general consists of clean zone and non clean. The function of the holy boundary in the mosque building is connecting of area between the place of ablution and the prayer room. The nature of the holy boundary space is a clean area. This study will know the space typology and analyze the relationship of the sacred boundaries in the layout of modern mosques in Makassar. Integration in the modern mosque layout is seen from the indicators of spatial layout, location, shape and circulation in the sacred boundary space. Methods of surveying, interviewing and observing sacred boundary areas in four modern mosques at Raya Mosque, Al-Markas Mosque, Amirul Mukminin Mosque and H.M Asyik Mosque. Data were analyzed descriptively qualitatively with drawing and tabulation schemes. The results of the study were obtained first, the typology of the space of modern mosque buildings in Makassar consisted of clean zone (prayer rooms, ablution rooms), transitional zone (sacred boundaries, foyer spaces and manager's office spaces) and non-clean zone (toilets, basement storage rooms feet, kitchen). There is a change in the function of the sacred boundary space as a liaison between the ablution room to the prayer room to be a liaison between the ablution room/toilet (clean zone and non -clean zone) to the porch/ prayer room (transition / clean zone). Second, the sacred boundary is viewed from the aspect of location, shape, circulation, user activity which has an impact on the layout of the mosque building. The most related aspect to the sacred boundary is the location and circulation system of the user in the layout of the mosque. The design concept of the location of the holy boundary in the layout of the mosque building must maintain the function of the holy boundary as a clean zone.
\end{abstract}

Keywords : Clean Zone; Typology; Modern Mosque.

\footnotetext{
${ }^{1}$ Teknik Arsitektur, UIN Alauddin Makassar

${ }^{2}$ Teknik Arsitektur, UIN Alauddin Makassar
} 


\section{PENDAHULUAN}

Ide awal peresmian prasasti BATAS SUCI bertujuan untuk memastikan kesucian lantai masjid dari najis dan kotoran yang terdapat pada alas kaki. Waktu masuk sholat ditandai adzan berkumandang otomatis berbondong-bondong orang menuju Masjid, Dimana kita sebagai umat muslim wajib menjaga kesucian tempat sholat, agar sholat kita khusyu (Ahmadi 2004). Sebagaimana bagian dari Masjid yang wajib dijaga kesuciannya adalah ruangan utama dalam Masjid untuk tempat sholat, teras Masjid yang juga digunakan untuk sholat, dan tempat berwudhu. Biasanya di ketiga tempat tadi terpampang papan pemberitahuan yang bertuliskan "BATAS SUCIMAAF BUKA ALAS KAKI", ini untuk mengingatkan kita agar selalu menjaga kesucian ke tiga tempat tersebut (Subhan Riyadi 2015)

Batas suci merupakan salah satu elemen penting dalam mendirikan sebuah masjid. Secara sederhana dapat diartikan sebagai area dimana harus melepaskan alas kaki baik sepatu maupun sandal, bagi siapa saja yang masuk ke masjid tanpa terkecuali. Batas suci bertujuan untuk memastikan kesucian lantai masjid dari najis dan kotoran yang terdapat pada alas kaki, kita sebagai umat muslim wajib menjaga kesucian tempat sholat, demi khusuknya sholat (Mokhtar 2005). Ruang masjid yang wajib dijaga kesuciannya adalah ruangan utama dalam masjid pada area tempat sholat, teras masjid yang juga digunakan untuk sholat, dan tempat berwudhu (Setiabudi 2008). Pada umumnya pola peruangan masjid biasanya dibagi dalam kelompok ruang, diantaranya; memiliki unsur utama misalnya, mihrab (tempat imam), area mimbar, tempat wudhu dan ruang shalat (Direktorat Urusan Agama 2010). Pada era modern Arsitektur Masjid berkembang dalam corak dan ragamnya, secara garis besar dikelompokkan menjadi tiga bentuk yakni; mengambil bentuk- bentuk lama dalam bahan dan konstruksi baru; mencampurkan yang lama dan yang baru (ekletikisme); sama sekali tidak ada unsur lama, kecuali adanya elemenelemen utama masjid yang tidak dapat dihilangkan (N. Utaberta, H. Othman, and M. Surat 2010).

Defenisi tipologi adalah suatu ilmu yang mempelajari segala sesuatu tentang tipe. Tipologi arsitektur atau dalam hal ini tipologi bangunan yang erat kaitannya dengan suatu penelusuran elemen-elemen pembentuk suatu sistem objek bangunan atau arsitektural (Aufa 2015). Analisa tipologi salah satu metode dalam mendefinisikan atau mengklasifikasikan objek arsitektural, mengidentifikasi perubahan yang terjadi pada suatu objek dan analisa perubahan tersebut. Menurut (Direktorat Urusan Agama 2010) terdapat standarisasi ruang masjid yaitu; ruang utama, ruang shalat, ruang wudhu, ruang pelayanan dan ruang penunjang; kegiatan pendidikan dan musyawarah. Adapun klasifikasi masjid berdasarkan wujudnya . Menurut Abu Dhabi Mosque Development Regulation bahwa, "Masjid dapat di klasifikan dalam masjid kecil (mushollah), masjid Jami (besar/agung), dan distrik Jame'e. Distrik Jame'e adalah suatu wilayah yang digunakan untuk shalat, biasanya berdekatan dengan area open space, dapat digunakan untuk melayani shalat harian, shalat Ied dan shalat Jumat. Karakteristik dapat dilihat pada tabel berikut : 


\begin{tabular}{|c|c|c|c|c|}
\hline PT 1 & PT2 & PT3 & PT4 & PT 5 \\
\hline 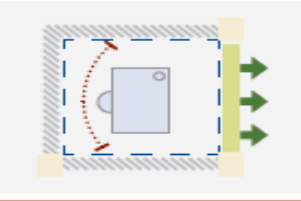 & $\frac{1}{<---1} 1 \Rightarrow$ & $\begin{array}{l}\Rightarrow \\
1 \Rightarrow\end{array}$ & 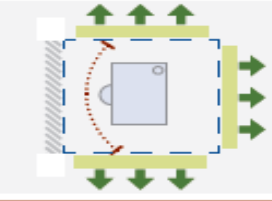 & 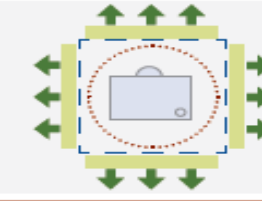 \\
\hline \multicolumn{5}{|l|}{ Characteristics } \\
\hline $\begin{array}{l}\text { Infill plots or } \\
\text { plots with } \\
\text { supporting community } \\
\text { facilities located } \\
\text { around them. }\end{array}$ & $\begin{array}{l}\text { Located on a corner } \\
\text { with } 2 \text { pedestrian/ } \\
\text { vehicular frontages. }\end{array}$ & $\begin{array}{l}\text { Located within a mid- } \\
\text { block and is accessible } \\
\text { through } 2 \text { opposite } \\
\text { edges. }\end{array}$ & $\begin{array}{l}\text { Located on the end } \\
\text { of a block and is } \\
\text { accessible through } 3 \\
\text { edges. }\end{array}$ & $\begin{array}{l}\text { Four pedestrian/ } \\
\text { vehicular frontages. }\end{array}$ \\
\hline \multicolumn{5}{|l|}{ Opportunities } \\
\hline $\begin{array}{l}\text { Infill plots to develop } \\
\text { communities. }\end{array}$ & $\begin{array}{l}\text { Good visibility/ } \\
\text { accessibility. }\end{array}$ & $\begin{array}{l}\text { Good accessibility/ } \\
\text { moderate visibility. }\end{array}$ & $\begin{array}{l}\text { Good visibility/ } \\
\text { accessibility/ } \\
\text { circulation. }\end{array}$ & $\begin{array}{l}\text { Good visibility/ } \\
\text { accessibility. }\end{array}$ \\
\hline \multicolumn{5}{|l|}{ Constraints } \\
\hline $\begin{array}{l}\text { Circulation restricted } \\
\text { and poor accessibility } \\
\text { and visual recognition. }\end{array}$ & $\begin{array}{l}\text { Possible difficult } \\
\text { location for qibla } \\
\text { orientation. }\end{array}$ & $\begin{array}{l}\text { Insufficient separation } \\
\text { between adjacent } \\
\text { uses. }\end{array}$ & None. & $\begin{array}{l}\text { Over-provision of } \\
\text { circulation space. }\end{array}$ \\
\hline \multicolumn{5}{|c|}{ Typology Applicability } \\
\hline Masjid. & Masjid and jame'e. & Masjid and jame'e. & $\begin{array}{l}\text { Masjid, jame'e and } \\
\text { district jame'e. }\end{array}$ & $\begin{array}{l}\text { Jame'e and district } \\
\text { jame'e. }\end{array}$ \\
\hline
\end{tabular}

\section{Legend:}

\begin{tabular}{|c|c|c|c|c|}
\hline & Frontage & $|\cdots| \cdot \mid$ & Recommended qibla direction & Pedestrian/vehicular frontage \\
\hline $\mathbf{N}$ & Built form & 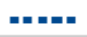 & Mosque Plot boundary & \\
\hline
\end{tabular}

Sumber: Abu Dhabi Mosque Development Regulation, Vol. 01

Menurut penelitian tentang desain ruang sholat (Mokhtar 2009) terlihat bahwa sirkulasi kegiatan mempengaruhi area suci dan tidak suci.

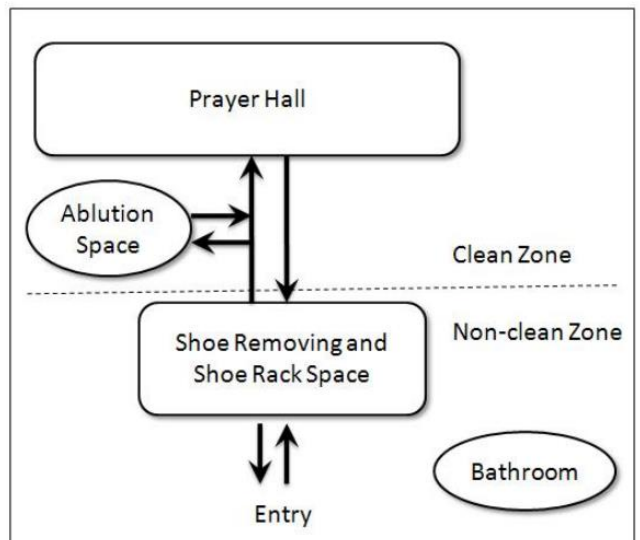

Gambar 1. Hubungan Ruang dan sirkulasi Kegiatan Sholat Sumber : (Mokhtar 2009)

Perkembangan Arsitektur Masjid di Indonesia memiliki tradisi dan budaya yang beragam. Masjid dalam pembangunannya tidak terlepas dari sejarah perkembangan Islam di wilayah tersebut, sehingga akan mempengaruhi bentuknya dengan jenis dan karakternya masing-masing (Suharjanto 2013). Pengaruh bentuk dan konsep dalam perkembangnnya kadang yang lebih dahulu ada, karena pengembangan dan pencampuran dari tempat dan jaman berbeda adalah hal yang lazim. Pencampurannya pun semakin kompleks dengan perkembangan budaya manusia dari jaman ke jaman. Adanya tuntutan desain tata ruang bangunan masjid yang perlu memeperhatikan kaidah dalam pembuatan sebuah masjid. Hal ini bertujuan untuk menjaga syarat dari fungsi 
bangunan masjid sebagai tempat ibadah. Batas suci sebagai salah satu bagian penting yang menghubung area kotor ke bersih memerlukan perhatian khusus dalam menataarea tersebut.

Dari penelitian ini diharapkan dapat memberikan pedoman kelayakan ruang yang semestinya dapat menjadi tolak ukur untuk mendesain masjid pada umumnya tanpa berbenturan dengan nilai-nilai Islam serta memberi kenyamanan fungsi bagi penggunanya. Pertama, dalam bidang keilmuan, Penelitian ini dapat memberikan tambahan wawasan bagi para Arsitek dalam pengembangan desain masjid utamanya pada masjid modern dengan nilai keislaman yang semestinya menjadi hal penting dalam syarat sahnya ibadah shalat. Kedua, penelitian ini diharapkan dapat memberikan informasi bagi masyarakat yang belum mengetahui keberadaan batas suci terhadap bangunan masjid utamanya pada masjid Modern serta dapat dijadikan rekomendasi dalam pengembangan masjid modern khususnya.

Tipologi ruang masjid secara umum terdiri dari area bersih/suci dan area kotor. Fungsi batas suci pada bangunan masjid merupakan area penghubung antara tempat wudhu dan ruang sholat. Sifat ruang batas suci adalah area bersih. Penelitian ini akan mengetahui tipologi ruang dan menganalisis hubungan batas suci pada tata ruang masjid modern di Makassar . Integrasi pada tata ruang masjid modern dilihat dari indikator tata ruang, letak, bentuk dan sirkulasi pada ruang batas suci. Metode survey, wawancara dan pengamatan area batas suci pada empat masjid modern dengan pertimbangan mewakili empat wilayah Makassar yaitu Masjid Raya, Masjid Al-Markas, Masjid Amirul Mukminin dan Masjid H.M. Asyik.

\section{METODE}

Metode penelitian yang digunakan dalam penelitian ini adalah metode diskriptif dengan menginput, menganalisis dan menginterpretasi data meliputi; tata ruang masjid (clean-zone dan non-clean zone), bentuk, letak, dan perilaku sifat penggunanya yang telah diidentifikasi terlebih dahulu. Data induktif yang didapat dilapangan diklasifikasikan dengan beberapa faktor-faktor yang berpengaruh terhadap batas suci, yang selanjutnya dijelaskan secara verbal. Berdasarkan permasalahan pada penelitian ini, maka metode yang dianggap sesuai adalah pendekatan kualitatif dengan strategi penelitian studi pada bangunan arsitektur masjid Modern. Selain itu digunakan metode studi literatur dari berbagai sumber literatur yang disarikan, kajian ini mencoba melakukan identifikasi awal, terhadap berbagai informasi tentang tipologi masjid dan penempatan ruang wudhu, toilet dan perilaku penggunanya dan kajian literatur dari hadits yang dianggap memiliki implikasi terhadap judul penelitian ini. Adapun teknik analisis yang digunakan adalah teknik analisa reduction and display data, dengan melihat gambar 1:

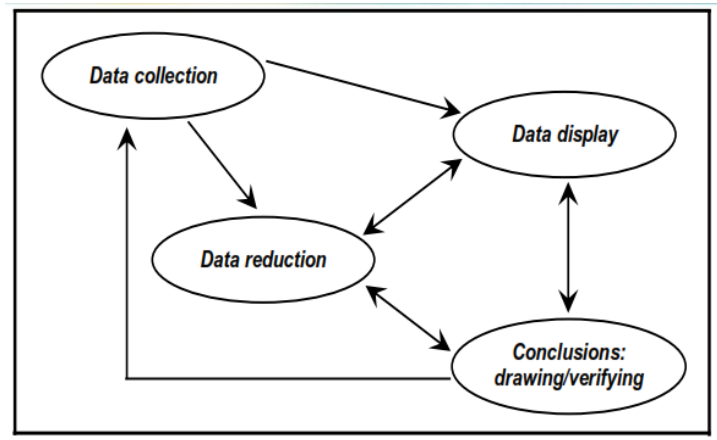

Gambar 2. Model interaktif komponen dalam analisis data Sumber: Miles dan Huerman,1992 dalam Sugiyono,2011 
Teknik mereduksi data adalah merangkum, memilih hal-hal pokok untuk mencari tema dan pola, data yang diperolah akan memberikan gambaran dan memperjelas untuk pengumpulan data yang diperlukan selanjutnya. Penelitian kualitatif ini mencari pola yang tersembunyi dari pola yang nampak. Display data dilakukan setelah mereduksi/merangkum data. Informasi yang telah tersusun akan memudahkan dalam menarik kesimpulan dan tindakan selanjutnya. Bentuk penyajian data tabulasi dapat memudahkan dalam memahami kasus dan acuan untuk mengambil tindakan berdasarkan pemahaman analisis data. Data penelitian dapat disusun berdasarkan penyajian bentuk uraian dengan matriks jaringan kerja. Display data dapat berupa tabel dan matriks sehingga penulis dapat menyimpulkan dan menjawab permasalahan dari penelitian.

\section{HASIL DAN PEMBAHASAN}

\section{A. Tipologi Ruang Masjid Modern di Makassar}

Tipologi ruang yang dimaksud adalah bagian tata ruang masjid yang meliputi posisi perletakan zona batas suci, tempat wudhu, ruang sholat, toilet serta penitipan sandal. Tata ruang yang sifatnya sebagai zona bersih (Clean Zone), zona tidak bersih (Non Clean Zone). Pembahasan selanjutnya yaitu mendiskripsikan tentang kondisi tata ruang masjid, zona clean dan tidak, letak dan bentuk batas suci dan sirkulasi serta aktivitas pengguna masjid pada area Masjid.Lihat tabel berikut :

Tabel 2. Analisa Batas Suci pada Tipologi Masjid Modern (Jami'), Al Markaz Al Islamic Center dan Masjid Raya Makassar

1. Situasi dan Perletakan Tata Massa Bangunan Masjid Al-Markaz Al-Islamic
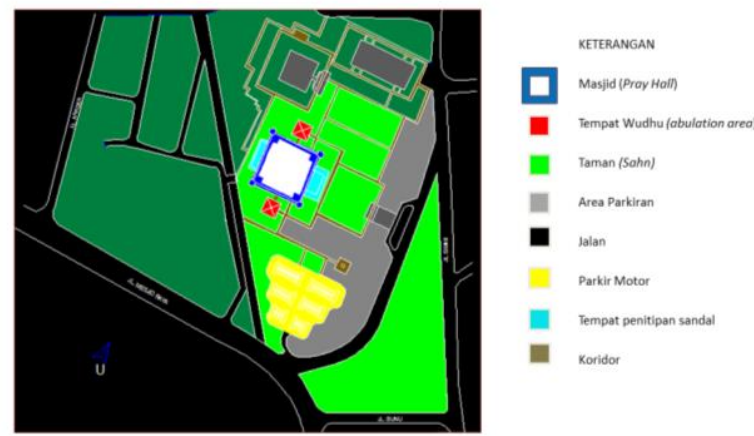

Bangunan berada pada lahan seluas 10 hektar yang terdiri dari bangunan utama Masjid serta penunjangnya tempat wudhu, menara masjid, halaman masjid dan halaman parkir. Tata letak masjid ini berada di antara dua jalur pencapaian jalan utama yakni jalan Masjid Raya yang berada di sebelah Selatan dan jalan Sunu sebagai jalan pendukung yang terletak disebelah Timur Masjid. Dibatasi oleh kanal di sebelah Barat dan jalan Lingkungan Kampus Universitas Hasanuddin lama disebelah Utara Masjid tersebut. Pada sebelah Barat Masjid ini terdapat lahan kosong yang rencananya akan di bangun sekolah pendidikan Islami.

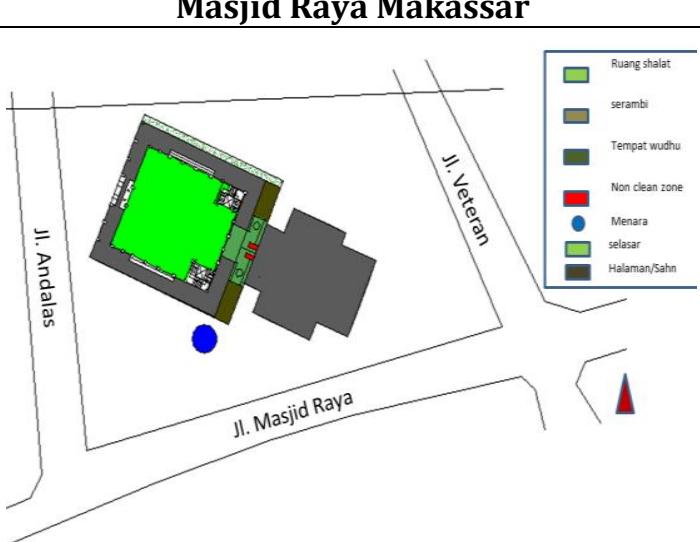

Masjid Raya diapit oleh tiga jalan besar. Sebelah Timur jalan Veteran, sebelah Selatan jalan Masjid Raya, dan sebelah Barat bersebelahan dengan Jalan Andalas. Sedangkan sebelah Utara masjid terdapat sekolah Islam.

Pada sisi depan masjid terdapat halaman depan yang menyerupai sahn dan halaman parkir disekeliling masjid, terdapat 4 (empat) menara pada masing-masing sudut masjid dan 1 (satu) menara yang paling tinggi yang berdiri disamping masjid. 


\section{Denah Pembagian Ruang Masjid dan Tempat Wudhu /Toilet}

\section{Masjid Al-Markaz Al-Islamic}

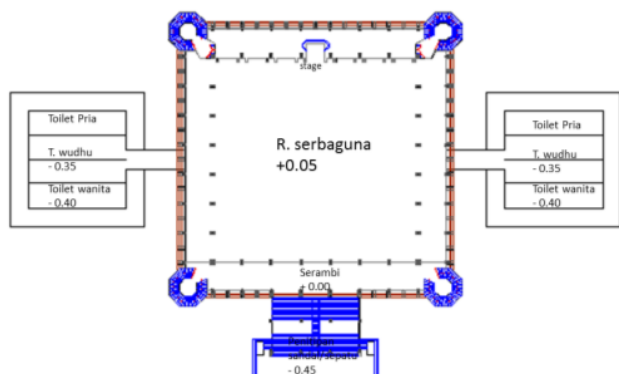

$\bigcirc^{\text {Denah LT.018 } 8 \text { T. Wudhut Toliet }}$

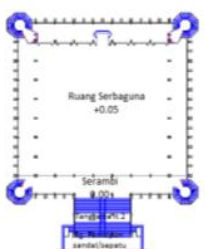

Oenertas

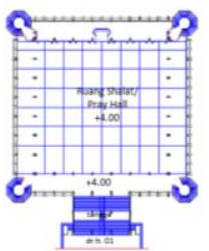

O)

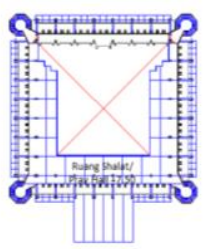

O
Masjid Raya Makassar
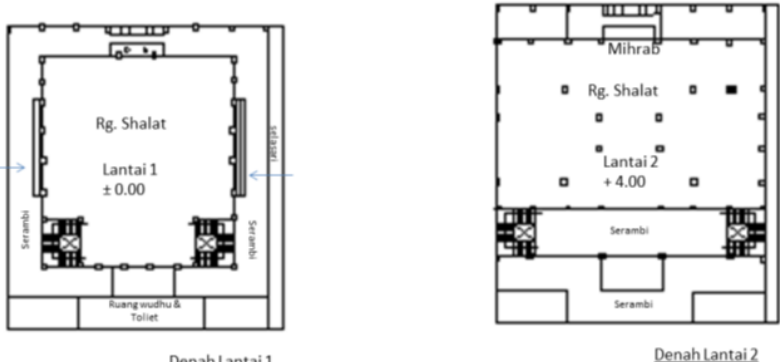

Denahlantai2

\section{Letak Clean Zone dan Non Clean Zone} Masjid Al-Markaz Al-Islamic

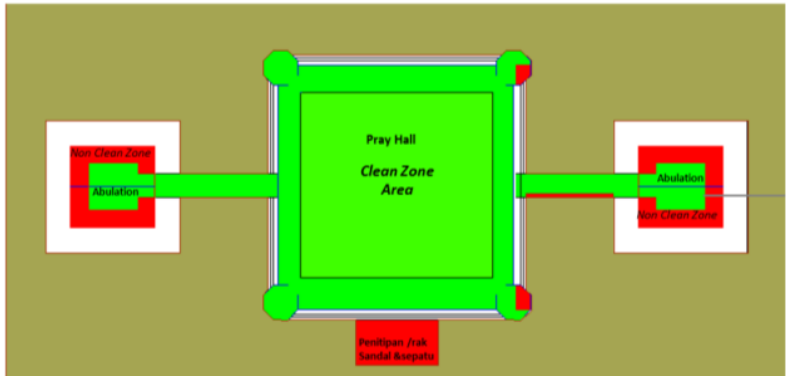

Letak clean zone berada pada area ruang shalat pada masjid (pray hall) dan tempat wudhu (abulation) sedangkan letak non clean zone berada pada area toilet dan tempat penitipan sandal/sepatu. Sebagian penitipan sandal ini ditempakan dibeberapa sisi masjid, diantaranya ; di bawah tangga dan koridor/selasar penghubung masjid.

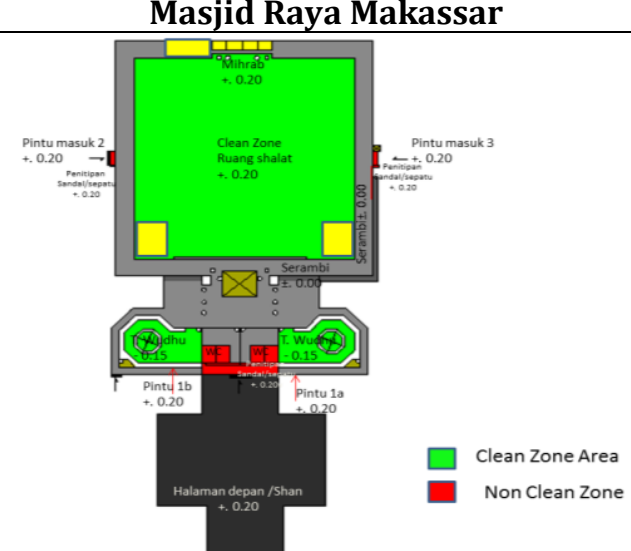

Letak clean zone pada Masjid Raya makassar berada diarea tempat shalat dan tempat wudhu. Zone clean dianggap sebagai area suci/area bersih pada masjid yang bebas dari kotoran/najis yang dapat membatalkan wudhu/shalat, sedangkan non clean merupakan area kotor/najis yang dapat dilalui oleh alas kaki( sandal/sepatu). Non clean zone masjid raya makassar ini berada pada area toliet dan tempat penitipan sandal/sepatu 


\section{Sirkulasi dan Kegiatan pengguna masjid clean zone dan non clean zone:}

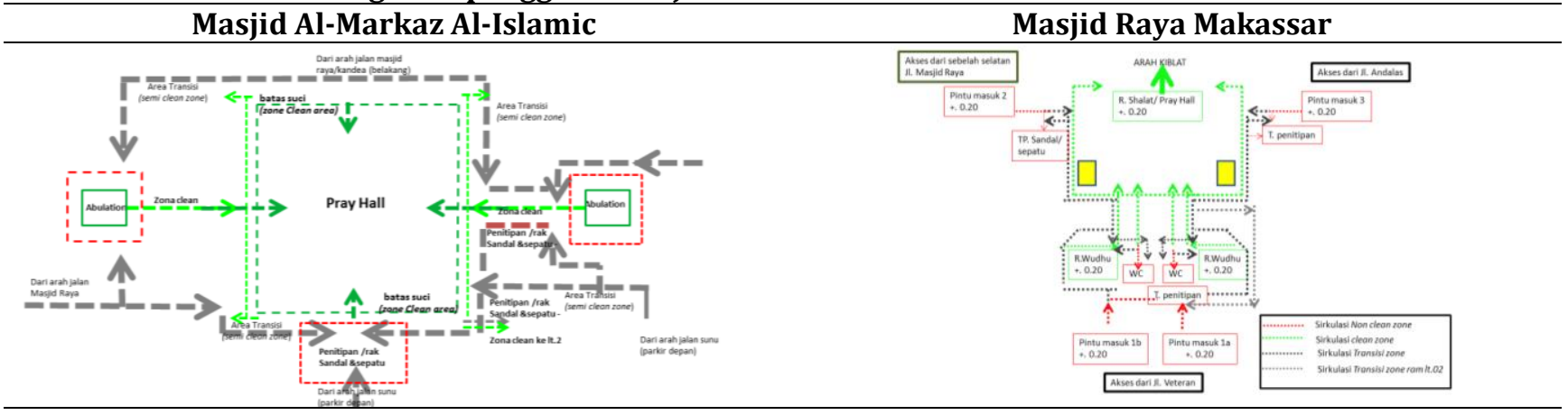

Jalur sirkulasi zone clean dan non clean zone pada masjid Al Markas Al Islamic ini melalui beberapa akses. Pertama melalui akses zone non clean dari arah jalan Masjid Raya menunju ke tempat wudhu, diarea ini melalui selasar penghubung menuju masjid, area ini tidak disediakan tempat penitipan sandal/sepatu, karena tempat penitipan sandal berada pada area arah depan masjid maka akses harus menuju ke tempat penitipan sandal/sepatu terlebih dahulu, kemudian melewati tangga yang ada di keliling masjid, selanjutnya akses zone clean menuju masjid melewati tempat wudhu kemudian koridor ke arah ruang shalat.

Kedua, akses dari arah parkiran depan masjid jalan sunu, pencapaian non clean zone dapat melewati arah depan masjid dan terdapat penitipan sandal/sepatu selain melalui tangga keliling serambi, area serambi masjid menuju ke tempat toilet, adapula tempat penitipan diarea bawah tangga dari arah lain dapat menitipkan sandal/sepatunya dan pada tempat penitipan di area koridor sebelah kiri masjid ini. Pencapaian zone clean dapat melalui tempat wudhu (abulation), kemudian koridor serambi dan ke lantai 1, 2, dan 3.

Ketiga; pencapaian dari arah jalan Kandea (di belakang masjid), akses menuju non clean zone, melalui arah serambi belakang dapat menitipkan sandal diarea tempat penitipan bawah tangga dan diarea tangga serambi, setelah itu menuju toilet kiri dan kanan masjid melalui serambi masjid. Untuk zona clean-nya dari tempat wudhu menuju koridor kemudian serambi dan ke ruang shalat (zone clean).

Foto aktivitas di area transisi tempat wudhu (abulation area) di masjid Al Markaz Al Islamic

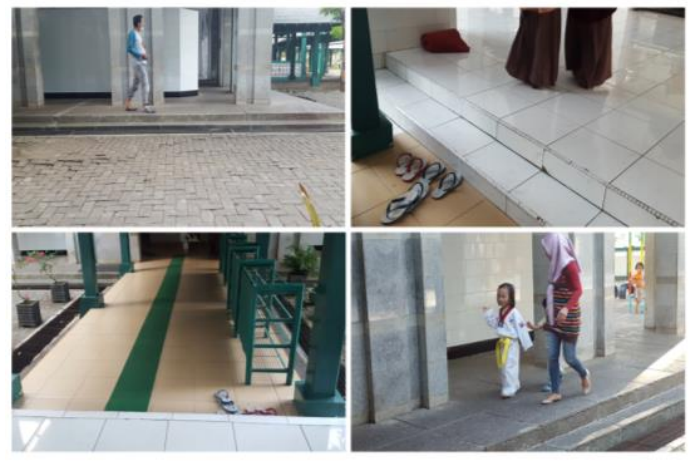

Jalur sirkulasi zone clean dan non clean zone pada masjid Raya Makassar memiliki akses yang melalui beberapa pintu masuk. Pertama akses zone non clean dari arah depan masjid dari jalan Veteran menunju ke tempat toilet/WC, di area ini melalui halaman depan masjid kemujian selasar penghubung tempat wudhu yang mengelilingi area tempat wudhu menuju ke tolilet/wc, diarea ini disediakan tempat penitipan sepatu pada pintu sebelum menuju selasar tempat wudhu. Akses kedua dari arah sebelah selatan/jalan Masjid Raya, pada area ini juga difungsikan sebagai area parkiran, akses melalui pintu masuk sebelah selatan masjid diarea ini disediakan tempat penitipan sandal dan selanjutnya masuk kearea masjid melalui serambi masjid sebelah selatan menuju ke tempat toilet/WC.

Akses ke tiga, melalui pintu masjid sebelah utara yang melalui jalan andalas. diarea ini juga di gunakan sebagai area parkir, akses ke arah pintu masuk masjid lantai 1 (satu) ini disediakan tempat penitipan sandal/sepatu pada depan pintu masuk area masjid dan sebagian digunakan pada area serambi masjid, selanjutnya melalui serambi keliling masjid menuju ke toilet/WC. Adapun akses dari lantai 2 (dua) yang biasanya melewati ram dari lantai 2 (dua) yang terlebih dahulu harus menintipkan sandal ke lantai 1 (satu). Akses melalui ram ini berada di area depan ke arah sisi utara masjid, kemudian selanjutnya ke pintu sebelah utara masjid di lantai 1 (satu).

Untuk akses zone clean dari tempat wudhu menuju ke ruang shalat (pray hall), dapat melewati akses masuk dari non clean zone, tempat wudhu untuk laki laki dan perempuan terpisah begitupula dengan akses melalui pintu masuk tempat wudhunya.

Di area ini jalur sirkulasi yang dilewati oleh lakilaki besar kemungkinan ada yang melewati jalur balik dari non clean zone, karena akses pencapaian menuju area ruang shalat (pray hall) laki-laki itu berada diarea depan ruang shalat, berbeda halnya dengan akses bagi perempuan yang akan menuju area ruang shalat, mereka dapat langsung menuju ke area ruang shalat (clean zone), namun jika pintu yang digunakan hanya satu akses saja diarea tempat wudhu dan toilet maka kemungkinan akan melewati jalur balik dari akses menuju non clean zone. 


\section{Letak dan bentuk Batas Suci (Line Clean Zone)} Masjid Al-Markaz Al-Islamic

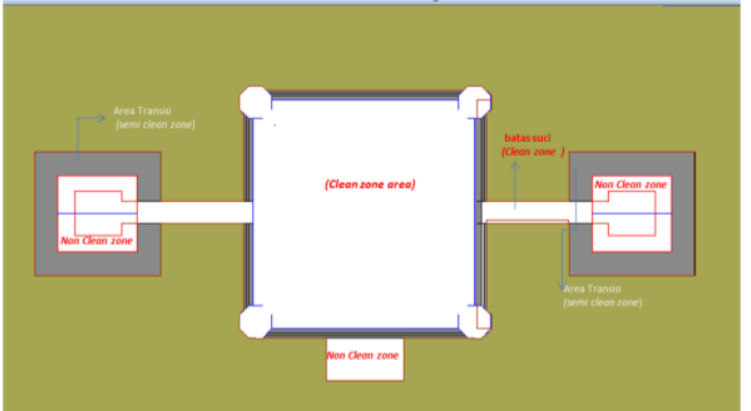

\section{Masjid Raya Makassar}
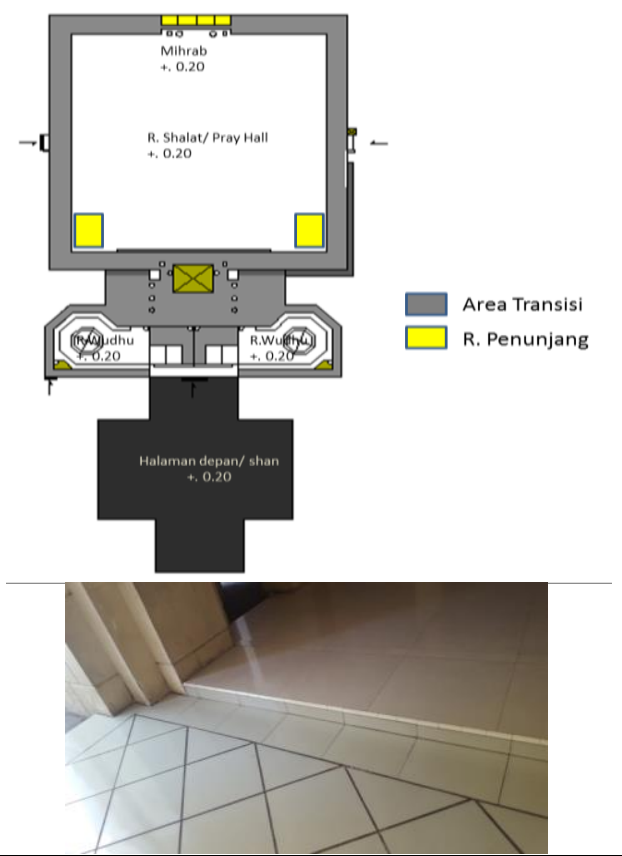

Sumber: Olah data, 2019

Pembahasan selanjutnya menjelaskana tentang data yang diperoleh pada masjid kecil Amirul muknin dan masjid H.M.Asyik (lihat tabel 2).

Tabel 3. Analisa Batas Suci pada Tipologi Masjid Modern (kecil), Amirul Mukminin dan HM. Asyik

\section{Situasi dan Perletakan Tata Massa Bangunan}

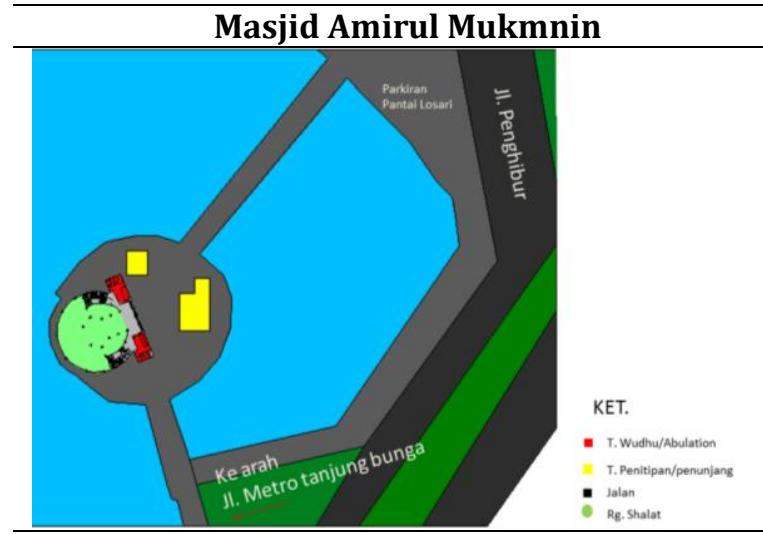

Masjid Amirul Mukminin berada di sekitar area pantai Losari. Mesjid ini dapat diakses memalui dua jalur yaitu Timur dan Selatan Masjid. Di jalur Timur berdekatan dengan area parkiran kawasan pantai Losari, sedangkan jalur Selatan berseberangan dengan jalan Penghibur. Lebar jalan menuju masjid ialah \pm 4 meter.

Ruang masjid Amirul Mukminin ini terdiri atas; ruang shalat, area wudhu, area toilet/WC, serambi dan tempat penitipan sandal/ sepatu. Posisi tempat wudhunya berada diarea depan masjid yang terpisah laki-laki sebelah kanan masjid dan perempuan di sebelah kiri masjid .

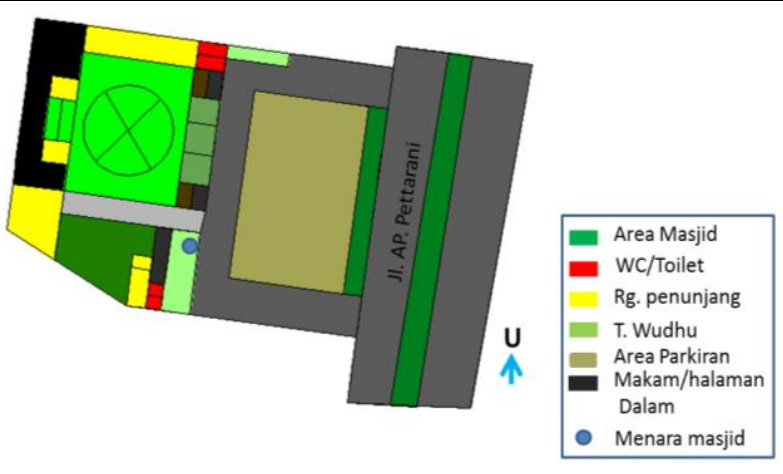

Masjid ini dapat diakses melalui jalan A.P. Pettarani Masjid ini diapit bangunan pertokoan dan rumah penduduk.

Ruang masjid ini terdiri dari: ruang shalat, mihrab, tempat wudhu laki-laki dan perempuan, toilet/WC, selasar, ruang kantor, gudang, ruang. alat, taman, makam yang berada di halaman dalam masjid, dan terdapat tempat penitipan sandal yang berada di pintu utama 


\section{Denah Pembagian Ruang Masjid dan Tempat Wudhu /Toilet}

\section{Masjid Amirul Mukminin}

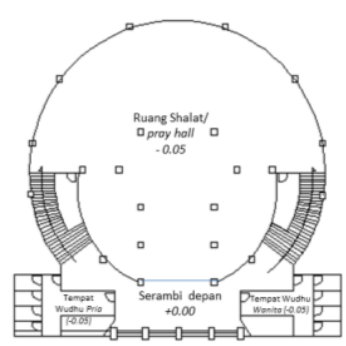

Lantai 01

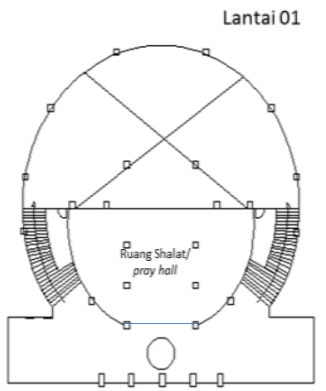

Lantai 02

\section{Masjid H.M.Asyik}
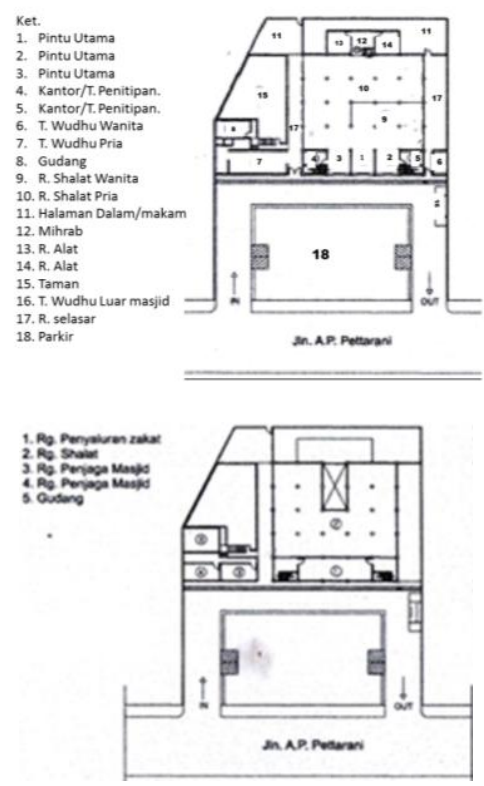

3. Letak Clean Zone dan Non clean Zone

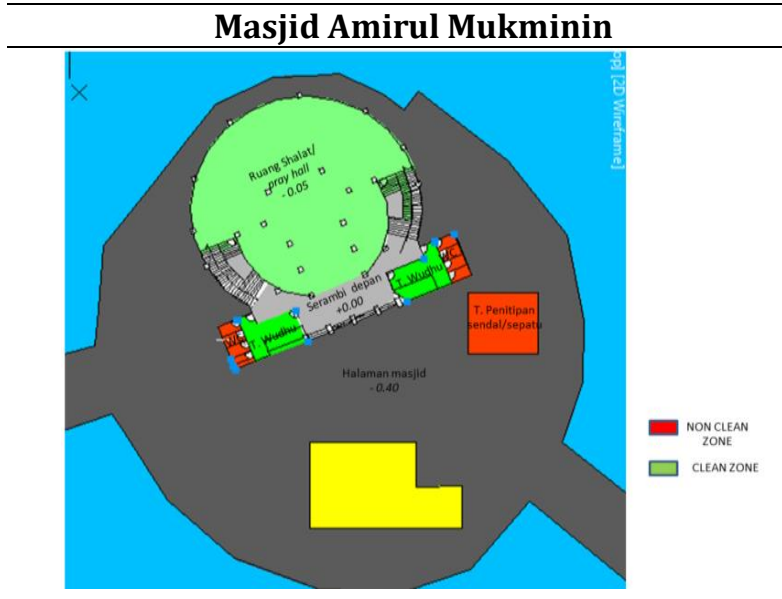

Letak clean zone pada masjid Amirul Mukminin ini berada diarea tempat shalat dan tempat wudhu. zone clean pada tempat wudhu ini terdapat ruang wudhu laki-laki dan perempuan masing-masing terpisah dibelah kiri dan kanan masjid. Area non clean zone pada masjid Amirul Mukminin ini berada pada area Toliet dan tempat penitipan sandal/sepatu.

Letak tempat penitipan sandal dan sepatu ini berada pada sisi kiri masjid dari arah depan pintu masuk. Tempat penitipan menggunakan tenda darurat, karena dalam perencanaan awal di masjid ini belum disediakan tempat penitan sandal/sepatu.

Sisi lain dengan melalui area samping masjid ini tidak terdapat tempat penitipan sandal /sepatu untuk menuju ke masjid. Area ini kemungkinan besar akan menimbulkan zone non clean ke letak batas transisi batas suci (clean zone).

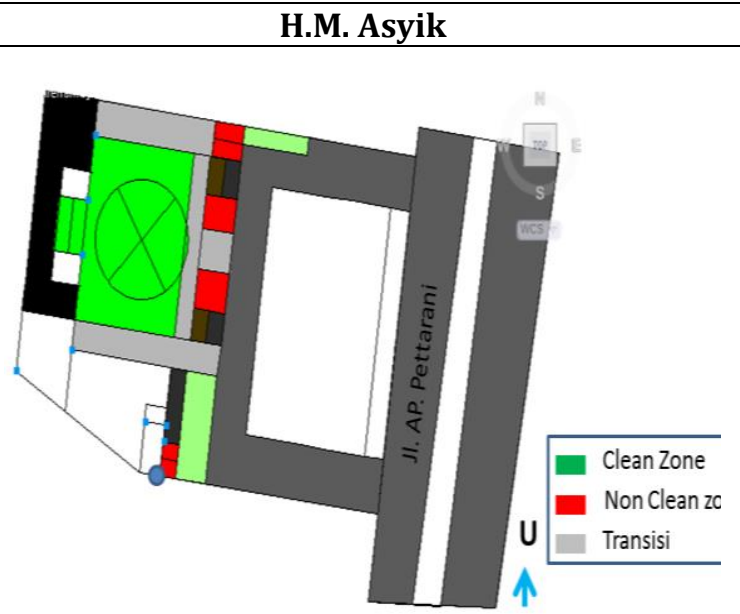

Area ruang shalat pada Masjid H.M asyik ini merupakan area clean zone, ruang shalat di masjid ini, dibagi atas ruang shalat laki-laki dan Perempuan. Area bersih juga terdapat pada ruang /tempat wudhu yang mestinya area bersih yang terbebas dari kotoran/najis. Pada masjid ini terdapat tiga tempat wudhu diantaranya adalah tempat wudhu laki-laki dan perempuan yang terdapat di area samping kiri (perempuan), kanan (lakilaki).

Sedangkan area yang belum dijamin bersih (non clean zone) pada Masjid H.M Asyik ini berada pada area toliet dan tempat penitipan sandal/sepatu. Letak tempat penitipan sandal dan sepatu ini berada pada posisi pintu masuk utama masjid di sisi kiri dan kanan pintu masuk utama masjid dari arah depan, sedangkan toilet berada pada area tempat wudhu yang akses masuk melewati tempat wudhu pada tempat wudhu laki-laki terdapat disamping kanan masjid. Di area ini terdapat pintu masuk dari depan langsung ke wudhu/toilet. 
Alas kaki dibuka ditangga sebelum masuk ke pintu ke 2 (dua). Hal ini akan menimbulkan non clean zone ke area tempat wudhu, karena dilalui kembali dari arah WC/toilet. Toilet juga terdapat di area tempat wudhu perempuan di sebelah kiri masjid ini harus melalui pintu depan.

\section{Sirkulasi dan Kegiatan pengguna masjid clean zone dan non clean zone:}

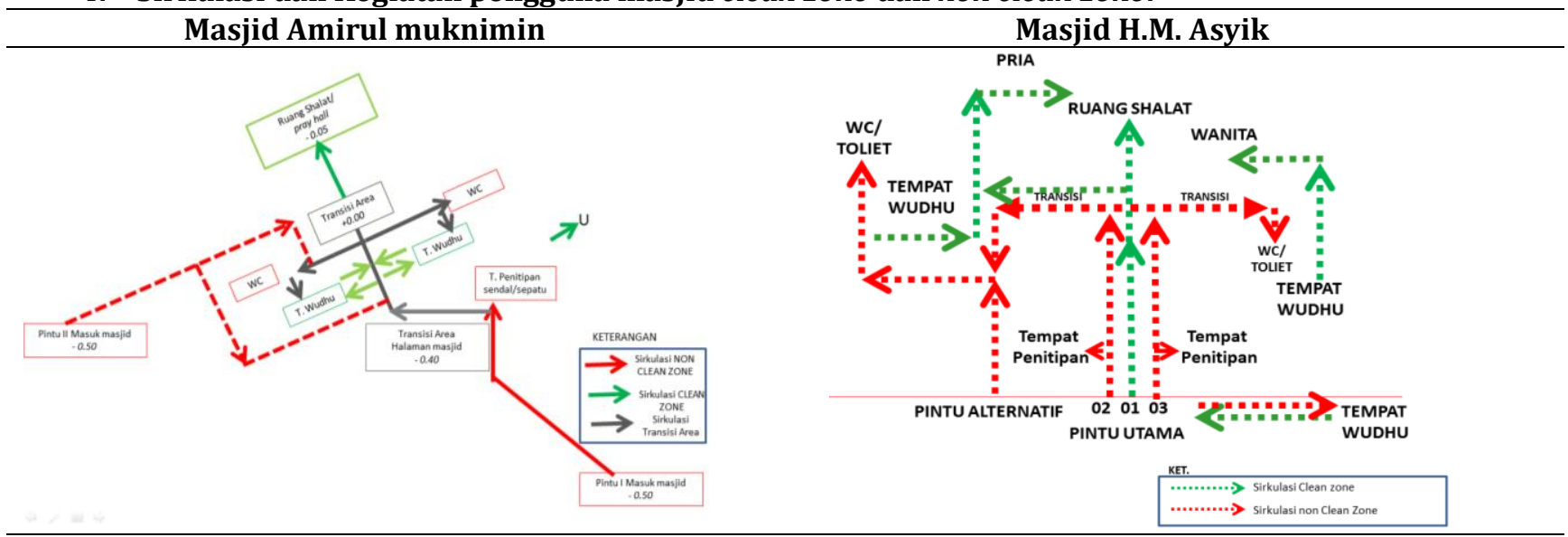

Jalur sirkulasi zone clean dan non clean zone pada masjid Amirul mukminin ini memiliki akses yang melalui 2 (dua) pintu masuk. Pertama akses zone non clean dari arah depan masjid dari arah Anjungan (Pantai Losari) menunju ke tempat Penitipan sandal terlebih dahulu, diarea ini melalui selasar penghubung/ dermaga masjid kemudian ke halaman depan masjid menuju tempat wudhu yang terdapat diselah kiri \& kanan masjid ini.

Terdapat 2 (dua) pintu masuk pada area tempat wudhu, yaitu akses langsung menuju tempat wudhu dan akses ke WC/toliet melalui pintu samping. Akses kedua dari arah sebelah Selatan/Jalan Metro Tanjung Bunga, pada area ini tidak terdapat tempat penitipan di pintu masuk. Jadi sandal/sepatu dititip melalui area transisi masjid, ke depan tempat penitipan yang pertama.

\section{Letak dan bentuk Batas Suci (Line Clean Zone)} Masjid amirul mukminin
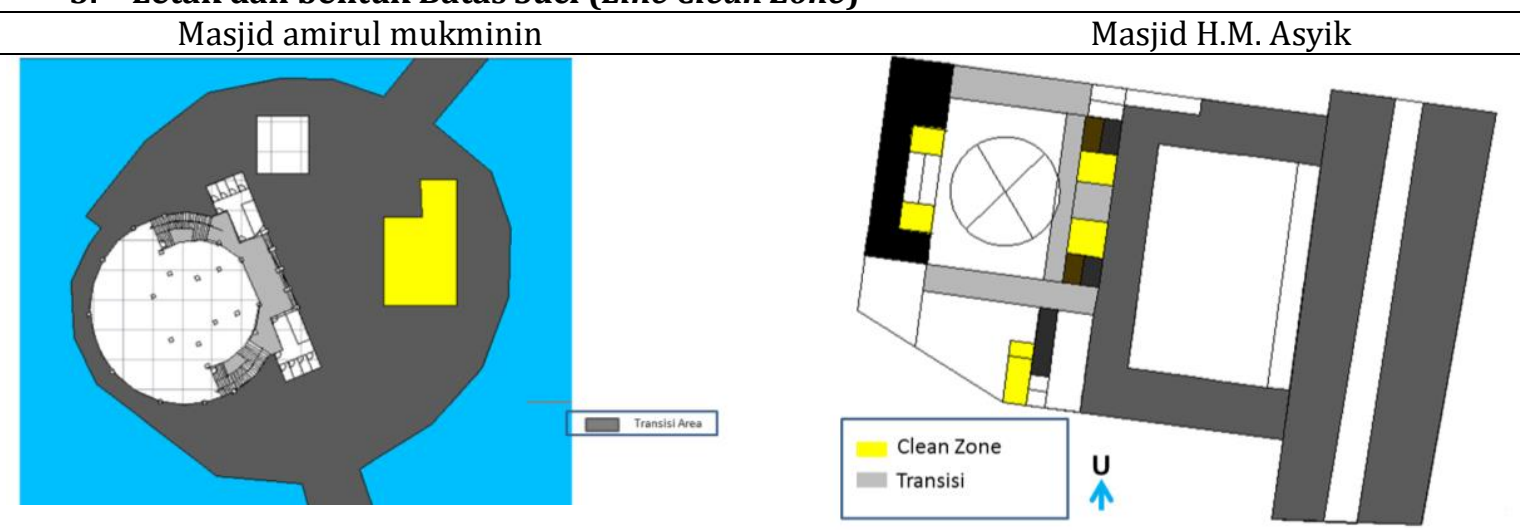


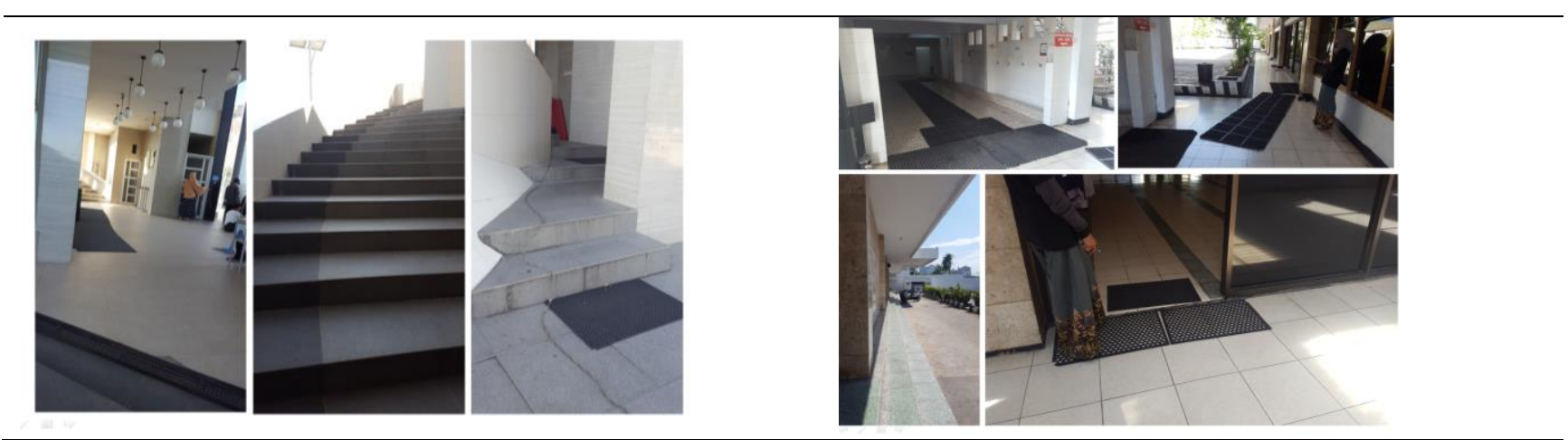

Sumber: Olah data, 2019

\section{B. Integrasi Batas Suci terhadap Tipologi Ruang Masjid Modern di Makassar :}

Berdasarkan data yang diperoleh tentang tata ruang, letak zona clean dan non clean, sirkulasi dan aktivitas yang terjadi di area batas suci dan letak serta bentuk batas suci yang digunkan pada ke -4 (empat) Masjid sebagai sampel, maka integrasi batas suci pada tata ruang dapat diketahui dengan melihat pada Tabel I. Analisis batas suci terhadap tipologi masjid Modern di Makassar dan mengetahui sejauhmana peran batas suci dalam tata ruang dalam menunjang fungsi bangunan sebagai bangunan masjid (lihat tabel).

Tabel 4. Analisis Batas Suci Pada Tata Ruang Masjid Modern di Makassar

\begin{tabular}{|c|c|c|c|c|c|}
\hline & Variabel & Masjid Al-Markas & Masjid Raya & Masjid Amirul Mukminin & Masjid HM. Asyik \\
\hline 1. & $\begin{array}{l}\text { Letak dan } \\
\text { Fungsi } \\
\text { Ruang Batas } \\
\text { suci }\end{array}$ & $\begin{array}{l}\text { Letak: adanya perbedaan } \\
\text { jarak Letak tempat } \\
\text { wudhu, tempat penitipan, } \\
\text { dan ruang shalat. } \\
\text { Ruangannya berjauhan } \\
\text { Fungsi : adanya fungsi } \\
\text { ruang serbaguna yang } \\
\text { berada antara tempat } \\
\text { wudhu dan tempat shalat }\end{array}$ & $\begin{array}{l}\text { Letak: adanya perbedaan } \\
\text { jarak letak tempat wudhu, } \\
\text { tempat penitipan, dan ruang } \\
\text { shalat. Ruanganya berjauhan } \\
\text { Fungsi: Peralihan fungsi } \\
\text { ruang shalat ke lantai } 01 \text { yang } \\
\text { dulu digunakan sebagai } \\
\text { fungsi ruang serbaguna yang } \\
\text { berada berdekatan dengan } \\
\text { tempat wudhu. }\end{array}$ & $\begin{array}{l}\text { Letak: perbedaan jarak } \\
\text { antara tempat wudhu } \\
\text { dengan penitipan sandal } \\
\text { berjauhan. Letak tempat } \\
\text { wudhu dan ruang shalat } \\
\text { berdekatan. } \\
\text { Fungsi: Ruang penitipan } \\
\text { sandal dibuatkan dengan } \\
\text { tenda tambahan diluar } \\
\text { bangunan masjid. }\end{array}$ & $\begin{array}{l}\text { Letak: perbedaan jarak } \\
\text { antara tempat wudhu dengan } \\
\text { penitipan sandal berjauhan } \\
\text { dan harus melewati ruang } \\
\text { shalat. } \\
\text { Fungsi: Adanya fungsi ruang } \\
\text { shalat yang difungsikan } \\
\text { sebagai ruang transisi } \\
\text { menuju ke tempat wudhu \& } \\
\text { Toilet dari luar tempat } \\
\text { penitipan sandal/sepatu. }\end{array}$ \\
\hline & Tanggapan & $\begin{array}{l}\text { Letak mudah dijangkau } \\
\text { namun jauh dari ruang } \\
\text { sholat Fungsi Batas } \\
\text { sangat tidak maksimal }\end{array}$ & $\begin{array}{l}\text { Letak strategis namun fungsi } \\
\text { batas sangat tidak maksimal } \\
\text { menjadi jalur sirkulasi } \\
\text { masuk-keluar masjid }\end{array}$ & $\begin{array}{l}\text { Letak berdekatan namun } \\
\text { fungsi batas kurang } \\
\text { maksimal karena tempat } \\
\text { wudhu bergabung dengan } \\
\text { Toilet }\end{array}$ & $\begin{array}{l}\text { Letak strategis namun fungsi } \\
\text { batas tidak maksimal karena } \\
\text { terdapat tempat yang wudhu } \\
\text { yang kadang dibuka dan } \\
\text { ditutup }\end{array}$ \\
\hline 2. & $\begin{array}{l}\text { Letak Ruang } \\
\text { Clean zone } \\
\text { \& non Clean } \\
\text { zone }\end{array}$ & $\begin{array}{l}\text { Letak tempat wudhu dan } \\
\text { Toilet berada dalam satu } \\
\text { ruang dengan satu pintu } \\
\text { masuk dan keluar.area } \\
\text { clean zone dan non clean } \\
\text { zone saling berdekatan }\end{array}$ & $\begin{array}{l}\text { Letak tempat wudhu dan } \\
\text { toilet berada dalam satu } \\
\text { ruang dengan satu pintu } \\
\text { masuk dan keluar area clean } \\
\text { zone dan non clean zone } \\
\text { saling berdekatan namun } \\
\text { jarak ke ruang shalat tidak } \\
\text { begitu jauh }\end{array}$ & $\begin{array}{l}\text { Letak tempat wudhu dan } \\
\text { toilet berada dalam satu } \\
\text { ruangan namun dapat } \\
\text { dijangkau dengan pintu } \\
\text { akses lainnya. Zona non } \\
\text { clean dapat melewati pintu } \\
\text { samping. }\end{array}$ & $\begin{array}{l}\text { Letak tempat wudhu dan } \\
\text { toilet berada dalam satu } \\
\text { ruangan dengan pintu masuk. } \\
\text { Zona non clean /toilet } \\
\text { perempuan masuk melewati } \\
\text { zona clean (ruang shalat } \\
\text { perempuan). }\end{array}$ \\
\hline & Tanggapan & $\begin{array}{l}\text { Terjadi percampuran } \\
\text { zona clean dan non clean } \\
\text { pada satu area ( ruang } \\
\text { sholat dan batas,tempat } \\
\text { wudhu) }\end{array}$ & $\begin{array}{l}\text { Terjadi percampuran zona } \\
\text { clean dan non clean (tempat } \\
\text { wudhu dan toilet bergabung) }\end{array}$ & $\begin{array}{l}\text { Terjadi percampuran zona } \\
\text { clean dan non clean (tempat } \\
\text { wudhu bergabung dengan } \\
\text { toilet) }\end{array}$ & $\begin{array}{l}\text { Terjadi percampuran zona } \\
\text { clean dan non clean (ruang } \\
\text { sholat menjadi batas suci ) }\end{array}$ \\
\hline 3. & $\begin{array}{l}\text { Bentuk } \\
\text { Batas Suci }\end{array}$ & $\begin{array}{l}\text { Bentuk yang digunakan; } \\
\text { keset kaki pada koridor, } \\
\text { tangga, serambi. }\end{array}$ & $\begin{array}{l}\text { Bentuk yang digunakan } \\
\text { material tegel yang dapat } \\
\text { menyerap air, serambi dan } \\
\text { tangga peralihan ke ruang } \\
\text { shalat }\end{array}$ & $\begin{array}{l}\text { Bentuk yang digunakan; } \\
\text { keset kaki pada area depan } \\
\text { tempat wudhu dan } \\
\text { dibersihkan dgn pel oleh } \\
\text { cleaning service masjid }\end{array}$ & $\begin{array}{l}\text { Bentuk yang digunakan; } \\
\text { keset kaki di bagian batas } \\
\text { luar ruang shalat yang berada } \\
\text { di area ruang penunjang pada } \\
\text { sisi kiri dan kanan masjid }\end{array}$ \\
\hline & Tanggapan & $\begin{array}{l}\text { Bervariasi namun belum } \\
\text { berfungsi maksimal } \\
\text { (menjadi jalur sirkulasi } \\
\text { umum) }\end{array}$ & $\begin{array}{l}\text { Bervariasi namun belum } \\
\text { berfungsi maksimal (menjadi } \\
\text { jalur keluar masuk masjid) }\end{array}$ & $\begin{array}{l}\text { Cukup efektif karena } \\
\text { dibantu oleh petugas } \\
\text { pembersih yang selalu } \\
\text { bertugas }\end{array}$ & $\begin{array}{l}\text { Cukup efektif namun tidak } \\
\text { terjaga kebersihannya }\end{array}$ \\
\hline 4. & $\begin{array}{l}\text { Sirkulasi } \\
\text { pengguna }\end{array}$ & $\begin{array}{l}\text { Banyak terjadi cross } \\
\text { sirkulasi antara zone }\end{array}$ & $\begin{array}{l}\text { Kadang terjadi cross sirkulasi } \\
\text { diantara zone clean dan non }\end{array}$ & $\begin{array}{l}\text { Tidak terjadi cross sirkulasi } \\
\text { jika melalui pintu samping }\end{array}$ & $\begin{array}{l}\text { Kadang terjadi cross sirkulasi } \\
\text { diantara clean dan non clean }\end{array}$ \\
\hline
\end{tabular}


\begin{tabular}{r|r} 
Integrasi Batas Suci terhadap Tipologi Ruang Bangunan Masjid Modern & Marwati*, Sutriani \\
\cline { 2 - 2 }
\end{tabular}

\begin{tabular}{lllll}
\hline Variabel & Masjid Al-Markas & \multicolumn{1}{c}{ Masjid Raya } & Masjid Amirul Mukminin & \multicolumn{1}{c}{ Masjid HM. Asyik } \\
\hline $\begin{array}{l}\text { pada area } \\
\text { batas suci }\end{array}$ & $\begin{array}{l}\text { clean dan non clean pada } \\
\text { area batas suci. }\end{array}$ & clean zone ada area & menuju non clean zone & $\begin{array}{l}\text { di area tempat wudhu laki- } \\
\text { laki dan cross pada area } \\
\text { ruang shalat (pray hall) }\end{array}$ \\
\hline Tanggapan & $\begin{array}{l}\text { Perlunya dibatasi arah } \\
\text { sirkulasi }\end{array}$ & $\begin{array}{l}\text { Perlunya pembatasan } \\
\text { sirkulasi }\end{array}$ & $\begin{array}{l}\text { Perlunya pemisahan antara } \\
\text { toilet dan tempat wudhu }\end{array}$ & $\begin{array}{l}\text { Perlunya peisahan jalur ke } \\
\text { ruang sholat dengan tempat } \\
\text { wudhu }\end{array}$ \\
\hline
\end{tabular}

Sumber: Olah data, 2019

Tabel 5. Dampak batas suci pada tata ruang masjid modern dan tanggapan desain

\begin{tabular}{|c|c|c|c|c|}
\hline & $\begin{array}{c}\text { Masjid A } \\
\text { (Al Islamic Al Markaz) }\end{array}$ & $\begin{array}{c}\text { Masjid B } \\
\text { (Masjid Raya Makassar) }\end{array}$ & $\begin{array}{c}\text { Masjid C } \\
\text { ( Masjid Amirul Muminin) }\end{array}$ & $\begin{array}{c}\text { Masjid D } \\
\text { (H.M. Asyik) }\end{array}$ \\
\hline $\begin{array}{l}\text { Dampak yang } \\
\text { terjadi pada } \\
\text { Batas Suci }\end{array}$ & $\begin{array}{l}\text { Terjadi daerah transisi } \\
\text { (terjadi Perubahan area } \\
\text { clean menjadi non clean) } \\
\text { antara clean zone ke non } \\
\text { clean zone pada batas } \\
\text { suci. }\end{array}$ & $\begin{array}{l}\text { Terjadi daerah transisi di } \\
\text { sekitar serambi dan area } \\
\text { tangga menuju ke ruang } \\
\text { shalat (pray hall)/ batas suci } \\
\text { dan ini dapat menimbulkan } \\
\text { zona non clean. }\end{array}$ & $\begin{array}{l}\text { Terjadi transisi di area depan } \\
\text { pintu masuk ruang shalat } \\
\text { (pray hall), }\end{array}$ & $\begin{array}{l}\text { Terjadi daerah transisi di } \\
\text { sekitar ruang shalat yang } \\
\text { dapat berubah menjadi non } \\
\text { clean dan serambi } \\
\text { penghubung ke area ruang } \\
\text { shalat. }\end{array}$ \\
\hline
\end{tabular}

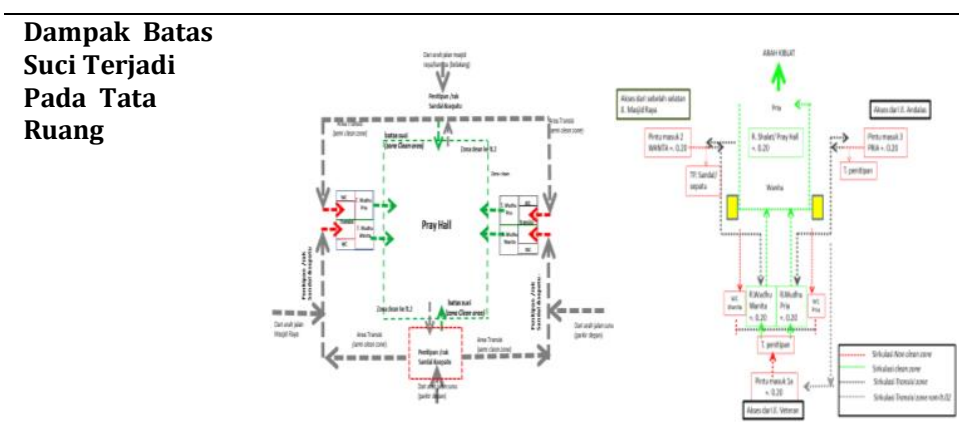
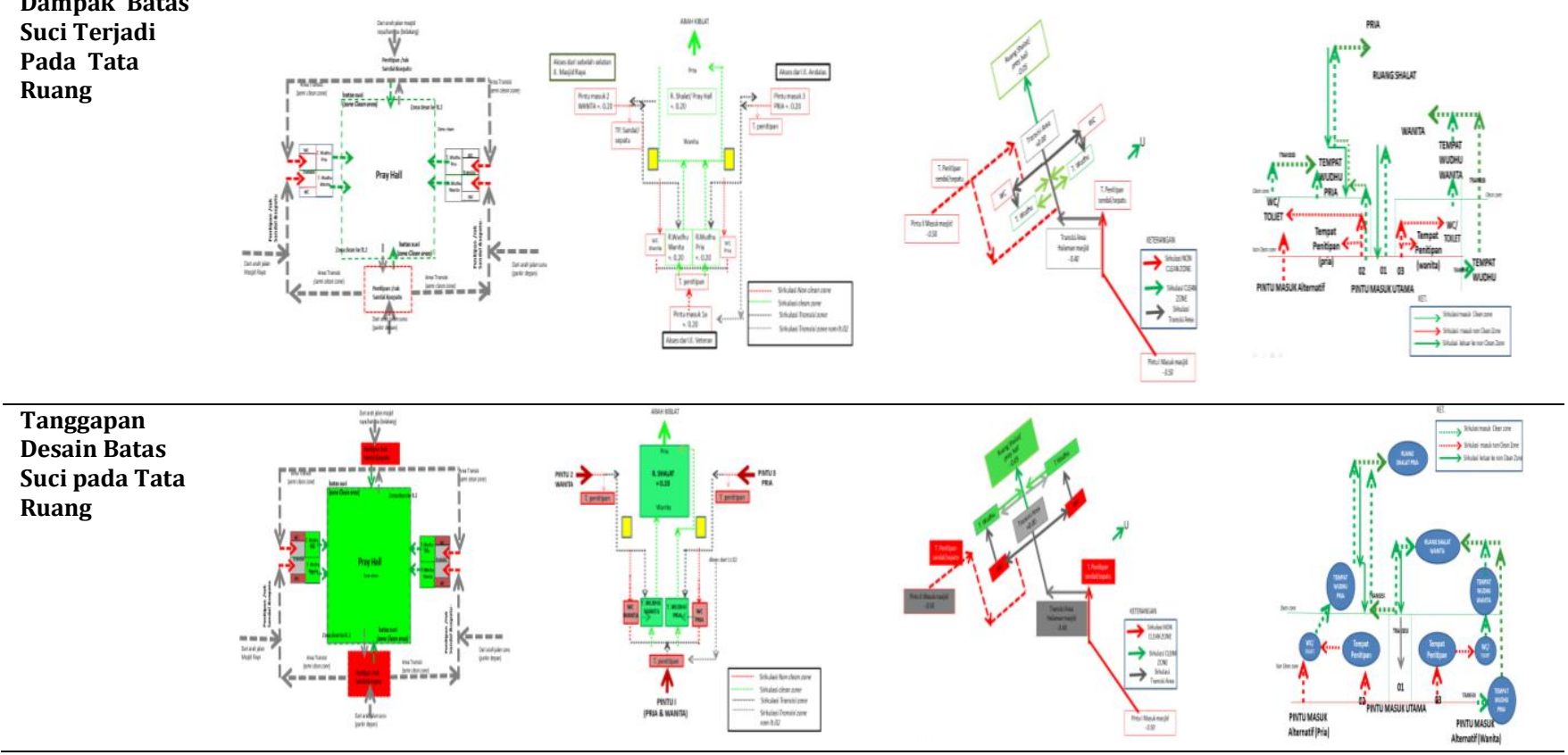

Sumber: Olah data, 2019

Berdasarkan tabel diatas dapat diketahui bahwa letak batas suci pada tata ruang masjid itu sangat berperan terhadap dampak yang ditimbulkan pada kegiatan sehari-hari seperti sirkulasi , aktivitas dan jaminan kebersihan pada ruang penghubung zona clean dan non clean (batas suci). Pembahasan diatas menjelaskan tentang variabel batas suci: letak, fungsi, bentuk, sirkulasi dan aktivitas. Untuk itu dapat diketahui tipologi ruang bangunan masjid modern yang ada di Makassar sebagian besar sudah memenuhi kebutuhan standar fungsi ruang sebuah bangunan masjid. Ruang batas suci namun fungsi ruang batas suci menjadi tidak efektif karena adanya tata ruang pada masjid tersebut. Faktor letak dan sirkulasi sangat berperan terhadap fungsi batas suci sebagai bagian tata ruang penting dalam sebuah masjid.

Berdasarkan dampak yang ditimbulkan oleh batas suci pada tata ruang bangunan masjid maka dapat diketahui konsep batas suci pada desain tata ruang masjid yang menjadi tanggapan desain yang dapat dilihat pada gambar berikut : 


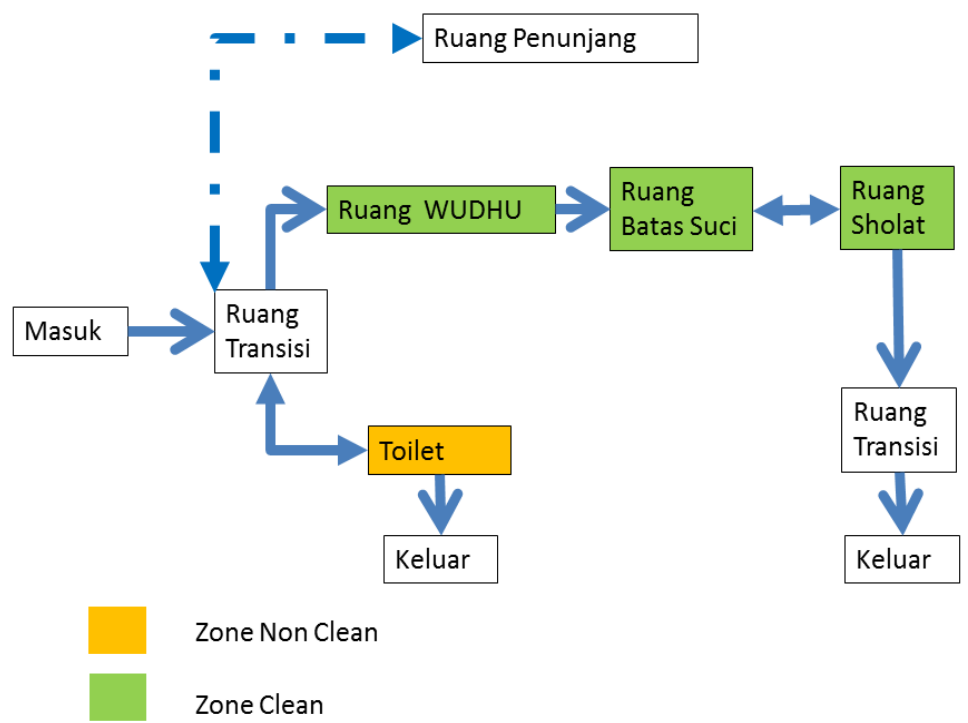

Gambar 3. Konsep ide batas suci pada tipologi ruang masjid Sumber: Hasil Analisis, 2019

Skema di atas merupakan konsep dasar yang bisa membantu menyelasaikan masalah fungsi batas suci pada masjid. Konsep diatas dapat menghasilkan beberapa tipologi ruang yang berbeda namun eksistensi batas suci tetap dipertahankan sebagai ruang zona clean .

\section{KESIMPULAN}

bahwa :

Berdasarkan permasalahan dan pembahasan hasil penelitian maka dapat disimpulkan

1. Tipologi ruang bangunan masjid modern di Makasar terdiri dari area bersih/suci (ruang sholat, ruang wudhu), area transisi (ruang batas suci, ruang serambi dan ruang kantor pengelola) dan area kotor (toilet, ruang penitipan alas kaki, dapur). Terdapat perubahan fungsi ruang batas suci sebagai penghubung antara ruang wudhu ke ruang sholat menjadi penghubung antara ruang wudhu/toilet (area bersih/suci dan kotor) ke serambi/ruang sholat (area transisi/bersih ).

2. Batas suci ditinjau dari aspek letak, bentuk, sirkulasi, aktivitas pengguna berdampak terhadap tata ruang bangunan masjid. Aspek yang paling berkaitan terhadap batas suci adalah letak dan sistem sirkulasi pengguna pada tata ruang masjid. Konsep desain letak batas suci pada tata ruang bangunan masjid harus menjaga fungsi batas suci sebagai zona clean.

\section{DAFTAR REFERENSI}

Ahmadi, Wahid. 2004. "Konsep Islam Dalam Arsitektur, Prosiding Simposium Nasional Arsitektur Islam,." In . Surakarta: Arsitektur UMS.

Aufa, Naimatul. 2015. "Tipologi Ruang Dan Wujud Arsitektur Masjid Tradisional Kalimantan Selatan." Journal of Islamic Architecture 1 (2): 53-59. https://doi.org/10.18860/jia.v1i2.1722.

Direktorat Urusan Agama. 2010. Peraturan Ditjen Bimas Islam. Jakarta: Departemen Agama. Mokhtar, Ahmed. 2005. Design Guidelines for Ablution Spaces in Mosques and Islamic Praying Facilities. American University of Sharjah. 
_- 2009. "Design Standards for Muslim Prayer Facilities within Public Buildings." ARCCLeadership in Architectural Research, Between Academia and the Profession, 163-69.

N. Utaberta, H. Othman, and M. Surat. 2010. "Dokumentasi, Analisis Dan Penggunaan Hadith: Satu Penilaian Keatas Rekabentuk Masjid Moden Di Malaysia." Journal of Building Performance 1 (1): 29-56.

Setiabudi, Bambang. 2008. Rumah Dalam Al Qur,an, Mailinglist Arsitektur Islam. Bina-ul Barakah.

Subhan Riyadi. 2015. "Batas Suci Bukan Pemanis Pondasi Masjid.” Kompasiana.Com, 2015. https://www.kompasiana.com/pipot/55485682547b618a162524d3/kaligrafi-batassuci-bukan-pemanis-pondasi-masjid.

Suharjanto, Gatot. 2013. "Keterkaitan Tipologi Dengan Fungsi Dan Bentuk: Studi Kasus Bangunan Masjid." ComTech: Computer, Mathematics and Engineering Applications 4 (2): 975. https://doi.org/10.21512/comtech.v4i2.2539. 